\title{
UCLA
}

InterActions: UCLA Journal of Education and Information Studies

Title

Market Values in Higher Education: A Review of the For-Profit Sector

Permalink

https://escholarship.org/uc/item/2q5856m8

Journal

InterActions: UCLA Journal of Education and Information Studies, 6(2)

ISSN

$1548-3320$

Author

Millora, Melissa L.

Publication Date

2010-05-27

DOI

10.5070/D462000682

Peer reviewed 


\section{Market Values in Higher Education: A Review of the For-Profit Sector}

A college education has long been viewed as a means for individuals to attain upward socioeconomic mobility (Bowen, 1982; Brint \& Karabel, 1989; Perkin, 2007). Whether students complete associate degrees at community colleges or transfer to a baccalaureate granting institution, completion of each additional level of education yields increases in income (Cohen, 1998; Cohen \& Brawer, 1982). Data gathered by the U.S. Census Bureau in 2005 indicate that individuals with associate degrees have a median income that is $\$ 9,000$ more than students whose highest education level is high school (Baum \& Ma, 2007). Data from the National Center for Education Statistics indicate that the median salary for male college graduates between the ages of 25 and 34 was $\$ 20,000$ more than their high school counterparts in 2008; for women it was $\$ 17,000$ more.

The income gains for graduates reflect a view that higher education benefits accrue to individuals and should therefore be conceived as a market endeavor. Changes in federal aid policy have facilitated this perspective. The 1965 Higher Education Act allowed for the availability and portability of financial aid, primarily in the form of loans. The legislation has made it possible for students from lower socioeconomic statuses to enroll in higher education (Thelin, 2004), thereby broadening access for students who would not be able to enroll without financial assistance (Gladieux \& King, 1999). On the surface, federal financial aid legislation appears to have broadened student access to higher education. However, the shift away from providing students aid in the form of grants to loans underlines the mentality that a college degree is a private good that an individual should purchase (Altbach, 1999; Gladieux \& King; 1999). The shift in federal student aid policy has also led to mixed results, yielding lopsided benefits to student loan recipients by diverting funds from students who would not be able to attend college without financial aid to upper and middle class students who would likely have attended college anyway (Gladieux \& King, 1999; Slaughter \& Rhoades, 2005). In addition, the portability of financial aid permitted students to choose where they would use their aid, creating a student-as-consumer mentality (Slaughter \& Rhoades, 2005). In turn, the "student-as-consumer" and the "student-as-potential-or-current employee who seeks workforce training or economic security" views detract from various aspects of the learning environment (Gumport, 2001, pp. 97-98). By requiring students to utilize their financial aid awards at accredited institutions, federal aid legislation forces institutions to comply with standards set by accrediting bodies, but it also promotes a market environment in the U.S. system of higher education (Cohen, 1998; Slaughter \& Rhoades, 2005). This article reviews the role that for-profit

institutions play against the backdrop of market values in higher education and 
lays the groundwork for future research that will further our understanding of the dynamics of this fast-changing sector.

\section{The Rise of For-Profit Higher Education}

For-profit institutions have been part of the landscape of American higher education since the seventeenth century when so-called matchbook schools, named for their method of advertising, taught reading, writing, and arithmetic to adults (Kirp, 2003; Lechuga, 2008). More than 300 years later the number of forprofit institutions has increased dramatically. The decade from 1990 to 2000 alone witnessed a $112 \%$ increase in the number of for-profits (Eckel, 2008). In 2006, at least 2,382 institutions had been classified as for-profit, 297 of which comprise $12 \%$ of the four-year degree-granting institutions in the United States (Breneman, Pusser, \& Turner, 2006). Two years later, out of the 6,632 institutions receiving federal student aid, 2,826 (43\%) were classified as private for-profit (National Center for Education Statistics [NCES], 2009a). Of the 2,286 for-profit institutions, 1,104 institutions granted associates degrees or higher (NCES, 2010).

The rise in the number of for-profit institutions has sparked a mixture of curiosity and anxiety about this budding sector of higher education. At the heart of the matter are the questions: What is the purpose of higher education and who benefits? Some believe that higher education should promote an educated citizenry presumably through liberal education (Bowen, 1977; Breneman, 2006; Dewey, 1916), while others primarily see higher education as a means for providing job training and employability (Lechuga, 2008). Altbach (1999) argues that throughout the 1980s and 1990s, students and employers have pushed colleges and universities to provide education that is more immediately relevant to the workforce. These growing demands may be one reason why for-profit higher education has succeeded. Success may also be related to the ability of forprofits to address questions of accountability (Altbach, 1999) or to their efficient organizational practices. To better understand the rise and success of for-profit institutions and their effect on the American system of higher education, it is important to examine the characteristics of for-profit postsecondary institutions.

\section{Diversity Among For-Profit Institutions}

The for-profit sector is comprised of all institutions that are ineligible for non-profit status and as such, these institutions have the freedom to do whatever they wish with their financial holdings (Kinser \& Levy, 2007). Institutions with programs that last fewer than two years make up approximately half of the forprofit sector (NCES, 2009a). Some for-profit institutions are multi-campus, while others are single campus or virtual; a few combine these various elements 
(Kinser, 2005). Owners include private groups, corporations, and publicly owned companies such as the Apollo Group, which owns the University of Phoenix and is traded on the NASDAQ and New York Stock Exchange (Kinser, 2007; Morey, 2004). Thirteen corporations own approximately seven percent of for-profit institutions, translating to 105 institutions that are associated with 526 individual campuses (Kinser, 2007). Perhaps the most well-known for-profit campus is University of Phoenix (UOP), owned by the Apollo Group, but DeVry and Kaplan may be equally familiar names. According to its website, UOP has more than 200 campuses throughout the U.S. In addition to its online programs, UOP offers associates, bachelors, masters, and doctoral degrees in a variety of fields. In contrast, the Academy of Art University, based in San Francisco, which also offers associates, bachelors, and masters programs, focuses entirely on art design. Finally, California Southern University and Capella University use only online delivery methods, and both offer bachelors, masters, and doctoral programs. There is tremendous diversity among for-profit institutions and the sector cannot be fully understood without careful documentation and additional research.

Curricular offerings and types of credentials or degrees awarded vary by institution (Breneman, Pusser, \& Turner, 2006; Morey, 2001). Thirty-nine percent of for-profit institutions are degree-granting and nearly half of those programs offer the associates degree; slightly more than one quarter of the degree-granting institutions offer the baccalaureate degree (NCES, 2009a). The remaining 1,722 non-degree-granting for-profit institutions comprise $77 \%$ of all non-degreegranting institutions receiving federal aid, or an impressive $26 \%$ of all institutions receiving federal aid.

Obtaining accurate and complete data about for-profit institutions is challenging due to the absence of an adequate classification system for the forprofit sector (Kinser, 2005). Distinctions between corporate universities, corporate-owned universities, non-degree-granting institutions, and degreegranting institutions are often not made, and within the degree-granting sector, statisticians, scholars, and others may not distinguish between multi-campus institutions and locally-based institutions (Kinser \& Levy, 2007). Even some of the government reports and empirical studies in this review did not distinguish between certificate-granting and degree-granting for-profit institutions. However, most scholars agree that the research literature focuses on the large, multi-campus institutions such as University of Phoenix, DeVry, and Strayer (Breneman, Pusser, \& Turner, 2006; Kinser, 2005). The majority of this review focuses on all types of degree-granting for-profit institutions with the occasional reference to certificate and non-degree granting programs. 


\section{Students}

Roughly 871,000 students are enrolled in for-profit higher education (Kinser, 2007). Within the for-profit sector, the profile of students varies between four-year institutions and less than four-year institutions. Students attending less than four-year institutions were more likely to be women, age 23 or younger, or independent. In contrast, students at four-year for-profit institutions were likely to be men, age 23 or younger, or independent. NCES also reported that $40 \%$ of independent students at less than four-year institutions are in the lowest income quartile compared to $25 \%$ at four-year institutions; conversely, $12 \%$ of independent students at less than four-year institutions were in the upper income quartile compared to $29 \%$ at four-year for-profits (NCES, 1999).

For-profit institutions focus most of their attention on adult students and other nontraditional learners, many of whom might not be admitted to traditional public or non-profit institutions (Breneman, 2005; Kirp, 2003; Morey, 2001). Students interested in for-profit institutions are looking for low-cost and convenient educational services (Morey, 2001). Convenience comes in the form of evening and weekend classes, distance learning, and campus locations that are in shopping malls and storefronts (Kinser, 2007). Despite the desire for a low-cost option, the NCES (2009a) reported that the average price of attendance for a fulltime, first-time degree seeking student at a two-year for-profit institution was $\$ 12,988$ in 2008-09 while it was $\$ 10,661$ at a private non-profit two-year and $\$ 2,835$ at a public two-year (at the in-state rate). The same report indicated that at for-profit four-year institutions, the average price of attendance for one year was slightly less than a private four-year, but approximately two and a half times that of a public four-year. Because tuition is an important source of revenue, students have the power to affect the bottom-line of the institutions (Kirp, 2003). Not surprisingly, for-profit institutions cater to the student-as-consumer and determine what curricular programs to offer based on potential for tuition profit (Morey, 2001).

Student financial aid has shifted largely from grants to loans, which seems to be impacting students' financial stability. Students at for-profit institutions are twice as likely to receive aid, but they also have excessively high default rates (Slaughter \& Rhoades, 2005). An analysis of data from 1995-1996 shows that students at for-profit two-year institutions received an average of $21 \%$ more aid than their counterparts at public community colleges (Alexander, 2002). A more recent report indicates that more students at two-year and less than two-year forprofit institutions receive aid than students in the equivalent public and non-profit institutions (NCES, 2009a). In terms of loans made directly to students, the average amount was greater for students at all for-profit institutions compared to their public and non-profit counterparts (NCES, 2009a). As an example, the 
average loan to a student attending a four-year for-profit institution was $\$ 6,989$. The average loan to a student at a public four-year was $\$ 4,433$ and $\$ 5,558$ at a private non-profit four-year institution.

Research has shown that substantial proportions of students at for-profit institutions default on loans (Dynarski, 1994; Grubb \& Turna, 1991; NCES, 1999; Volkwein, Szelest, Cabrera, \& Napierski-Prancl, 1998). However, some of the research is dated, and student loan scholars have pointed out the growing lapse in rigorous and robust research on student loan default and the need to re-engage in this research (Gross, Cekick, Hossler, \& Hillman, 2009). Dynarski (1994) argues that the federal student loan program is serving financially needy students, the group targeted by federal student aid policies, but these borrowers are more likely to default on their loans. They are also more likely to be students of color. Within each racial group, students at for-profit institutions had the highest or second highest rate of default when compared with public and private non-profit two-year colleges, four-year colleges, and research universities (Volkwein et al., 1998). Gross et al. (2009) suggest that default rates may be higher for students of color because they are borrowing at higher rates. They also suggest that post-graduation unemployment perhaps coupled with the absence of financial reserves makes repayment impossible. Despite the perception that for-profit institutions are a lowcost alternative and combined with data that suggest students at these institutions receive more financial aid, it may be that the debt burden of attending for-profit institutions creates insurmountable challenges to students in their effort to repay their loans. Similar to the recent mortgage crisis, it could also be that lenders are not taking into account realistic timeframes for students' repayment of their loans. Dynarski (1994) suggests that the government could extend the repayment period for students with low incomes or large family sizes. Regardless, the higher default rates in the for-profit sector call into question the claim that some proponents make regarding the effectiveness of for-profit education and the greater returns to the U.S. treasury on taxpayers' money (Sperling \& Tucker, 2006).

A related concern is the attrition rates at for-profit institutions. A recent report from the NCES (2009b) indicated that the graduation rate of full-time firsttime students at for-profit institutions was lower than their counterparts at other institutions. Whereas $53.5 \%$ of students at public four-year institutions and $63.7 \%$ at private non-profit four-year institutions completed the bachelor's degree or equivalent, only $24.5 \%$ of students at for-profit institutions completed the degree. Seventy percent of students at public less than two-year institutions and $75 \%$ of students at private non-profits in the same category completed their programs, whereas $64.9 \%$ of their counterparts in the for-profits completed. The interesting group to highlight is the two-year institutions where the trend is reversed. Twenty-two percent of students in public two-year institutions and 50.2\% of students in private non-profit two-year institutions completed their degrees or 
programs, while $60 \%$ of students in private for-profit two-year institutions achieved completion. This last statistic raises the question as to whether the lower rate of completion in the public and non-profit two-year institutions is masking higher rates of transfer to baccalaureate-granting institutions.

The research is slightly mixed about whether students who enroll in forprofit institutions experience tangible benefits as a result of the education received at the institution. Grubb and Turna (1991) claim that students who earned certificates from for-profit institutions did not earn higher wages and may even earn less than individuals for whom high school is the highest level of education. In contrast, Pusser and Doane (2001) suggest that students who complete programs at for-profit institutions earn higher wages. The example of a DeVry Institute of Technology graduate who reported a $275 \%$ increase in salary after completing her degree may support this notion (Glass, 1995), but more confirmatory data is necessary. Other researchers claim that for-profit institutions prepare students for employment by imparting two things: the social skills necessary for employment (Deil-Amen, 2006) and the training for employability (Breneman, 2006; Lechuga, 2008). In support of the claim that for-profit education translates to tangible individual benefits, a different case study of DeVry Institute, one of the largest for-profit higher education providers, indicates that as many as $95 \%$ of graduates get jobs within six months of graduating (Kirp, 2003). The high rate of job placement from DeVry is undoubtedly connected to the type of job training provided. In fact, most for-profit degree granting institutions offer programs that are designed to meet the needs of employers (Lechuga, 2008).

\section{Curriculum and Faculty}

For-profit institutions focus on providing vocational job training, and they cater to student-consumers and students' future employers, for-profits provide training in a variety of fields, though the most popular are computers, business, and health fields (Kinser, 2007). They offer vocational and technical training, as well as certificate programs, and continuing education (Lechuga, 2008). Initially, curricular programs offered by for-profits did not overlap with the programs offered by traditional non-profit institutions. However, in recent years, for-profits have begun to offer bachelors degrees and other advanced degrees, including teacher credentialing (Morey, 2001). Some schools, like the American Schools of Professional Psychology, even offer PhD programs (Kirp, 2003). This shift in services creates the possibility for increased competition between non-profits and for-profit higher education in providing part-time and continuing education to adults (Breneman, 2006).

The curricula for these programs are designed centrally and intended to meet the needs of the job market (Ruch, 2001), a practice some critics refer to as 
cherry picking (Kinser, 2007). Doing so helps for-profit institutions ensure consistency in their product while presumably keeping personnel costs down (Lechuga, 2008; Ruch, 2001). Although faculty members are consulted in the development of curricula, they do not have primary control (Lechuga, 2008; Morey, 2001). Instead, Lechuga (2008) explains that advisory boards and centrally located business personnel play a role in designing a curriculum that will prepare students to meet employers' needs. He explains that advisory boards are made up of professionals in the field who are selected by faculty. There may be one advisory board for every academic program or field of study, and each board functions to connect an institution to potential employees. This practice reflects a major difference between faculty in the for-profit and the traditional non-profit sector.

Only 3 to 8 percent of faculty teaching within the for-profit sector is tenured (Kinser, 2005). Faculty do not engage in research and instead carry larger teaching loads (Glass, 1995; Lechuga, 2008). The teaching function is the most important aspect of for-profit faculty work and faculty are valued for their professional experiences as opposed to disciplinary training (Kirp, 2003; Lechuga, 2008). Good teaching, in the eyes of student evaluators, becomes most important because for-profit institutions depend on high quality teaching to satisfy students and their satisfaction directly translates to tuition, which then translates to profits (Glass, 1995). Ineffective teachers are removed from the classroom through student and peer evaluations (Kirp, 2003). This type of quality assurance is key to continued faculty employment and institutions' accreditation. Unfortunately, the ways in which for-profits devalue disciplinary training and give little credit to faculty for research and publishing clearly communicate how for-profits view faculty members: as teachers-for-hire rather than academics (Lechuga, 2008).

In many for-profit institutions, a major tension exists between the academic and business divisions of the institution (Kirp, 2003). Because faculty do not conduct research and do not have the type of academic freedom enjoyed by their counterparts in traditional institutions, they do not have the same type of power in making decisions for the institution. They are also more subject to the influence of other actors within the institution. As mentioned, though faculty have some say in the development of curricula, decisions about curriculum outcomes and objectives are shaped by senior business personnel. Furthermore, because faculty are reliant on student evaluations for employment, there exists the possibility of forgoing academic rigor in favor of positive evaluations (Lechuga, 2008). Centralization and concentration of decision-making with administrators and business personnel, along with their student-consumer centered approach, may benefit all members of the institution in terms of speed, efficiency, and effectiveness (Ruch, 2001). It may be that the practices of for-profit institutions 
are not necessarily inferior to those at traditional institutions, but such practices further entrench market values in higher education.

\section{Accreditation}

All institutions that wish to participate in federal aid programs must be accredited by one of the accrediting agencies approved by the U.S. Department of Education (Cohen, 1998). Accreditation can be considered a form of quality assurance for higher education (Eckel, 2008; Breneman, Pusser, \& Turner, 2006) and may also provide legitimacy to for-profit institutions (Kinser, 2005). Most importantly, accreditation ensures that for-profit institutions are eligible to receive federal student aid (Eckel, 2008; Kirp, 2003).

The main sources of institutional regulation for all colleges and universities are national and regional accrediting agencies. National agencies can accredit any institution in the U.S. while regional agencies can only accredit institutions in a specifically defined region. The type of accreditation an institution has may affect a student's ability to transfer across institutions and perhaps her ability to pursue post-graduate study. Accrediting agencies are quite able in detecting problems with an institution's finances, facilities, or leadership, but historically, they are less skilled at evaluating student learning outcomes and instruction quality (Cohen, 1998). It is only recently that accreditation agencies have begun to pay attention to student satisfaction, retention, and impressions of educational quality (Strauss \& Volkwein, 2004).

Most for-profit institutions are content with national accreditation, which is believed to have less exacting standards, because it likewise makes them eligible for federal student aid programs, which are key sources of revenue (Kinser, 2005, 2007). In fact perhaps 90\% of for-profit institutions are accredited by one of two national agencies: the Accrediting Commission of Career Schools and Colleges of Technology (ACCSC), which dropped "technology" from its name in 2009, or the Accrediting Council of Independent Colleges and Schools (ACICS; Floyd, 2005). A brief review of the ACCSC and the ACICS accreditation standards published on their websites suggests differing standards. ACCSC provides a detailed section on standards for student learning, assessment, progress, and achievement while ACICS makes two brief references to student relations and student services. Although accreditation processes have come to emphasize student retention and learning outcomes over the past 10 years (Strauss $\&$ Volkwein, 2004), there is currently little research about the impact of changing accreditation standards on the managerial philosophies within the for-profit sector.

Kinser (2005) explains that if for-profit institutions do not obtain accreditation from a national accreditation agency, they must procure it from one of eight regional accreditation boards. He adds that although accreditation can 
provide necessary articulation agreements with other regionally accredited educational institutions, variation in regional accreditation standards creates the potential for "accreditation shopping" (p. 78). Kinser points to the record of the North Central accreditation commission as an example of what appears to be accreditation shopping. North Central has accredited all existing virtual universities in the United States and some for-profit institutions have moved their headquarters to the North Central region from areas where they were not able to obtain regional accreditation.

\section{Finances}

The main difference between the traditional non-profit sector and the forprofit sector of higher education is that the first order of business of for-profit institutions is to actively profit from their higher education endeavors (Morey, 2004). For example, for-profit institutions focus heavily on providing training in computers and telecommunications, business, and health professions, all of which are considered to be profitable programs. These cherry-picked programs (Kinser, 2007) yield profits in part because working adult students are often eligible for tuition reimbursement through their employers (Morey, 2004).

In today's grim economic circumstances, postsecondary institutions are now in competition for financial resources (Breneman, 2005). Compared to their non-profit peers, for-profit institutions have not always had the same access to state and federal government support. With fewer taxpayer dollars available to colleges and universities through federal student aid programs and research grants, fewer public funds are available to support higher education. As a result, higher education leaders have looked to private donors for support (Ruch, 2001). For-profit institutions are able to harness the deep pockets of venture capitalists, equity markets, private corporations, and publicly traded corporations, for capital (Breneman, 2005; Breneman, Pusser, \& Turner, 2006; Morey, 2004 Kinser, 2007). Despite the limited federal aid dollars available to higher education through student aid and institutional grants, many for-profits still rely heavily on public support, using their knowledge of student federal aid packages to determine their tuition prices (Gladieux \& King, 1999). In addition, although many students who spend their federal financial aid dollars at for-profit institutions default on their loans, the 1998 Higher Education Act has made it easier to appeal the penalties levied on student loan defaults (Slaughter \& Rhoades, 2005).

Profitability is one of the key factors that contribute to the success of forprofit institutions and investors consider the for-profit higher education sector a promising investment for several reasons. In a survey of eight education-market analysts, Ortmann (2001) finds that financial analysts regard education as a safe investment, even in times of economic recession. Although he does not discuss 
this finding in detail, he notes that the need for employers with information technology skills partially drives the demand for education, which may suggest steady if not high returns from year to year. For individuals and financial institutions whose primary concern is profit-making, the promise of continued growth and potential for high rates of return (Kinser, 2007; Morey, 2001, 2004) makes investing in for-profit education appealing.

Since for-profit institutions that are not publicly owned do not have to disclose their earnings and financial statements, it is difficult to know what their profit margins are. As an insider within the for-profit sector, Richard Ruch (2001) may have had easier access to information regarding the financial performance of 5 of the 13 corporations in the for-profit sector. He reports that from 1994-1999, the stock performance of the Apollo Group was 1538\%, while it was $743 \%$ for DeVry University, and $710 \%$ for ITT Educational Services. In 2009, an article published in The Chronicle of Higher Education reported that in the year 2014, the for-profit sector is projected to earn $\$ 41.7$ billion. The actual earnings for 2009 were estimated to be $\$ 26$ billion (Wilson, 2010).

\section{Understanding the Success of For-Profit Institutions}

There are several elements that contribute to the success of the for-profit sector: its profitability, the needs that for-profit institutions meet, and the access to postsecondary education that the sector provides to students. The sizable profit margins in for-profit institutions are made possible by a number of factors. Forprofit institutions that include multiple sites are able to capitalize on economies of scale; that is, they can centralize functions that must be carried out for all parts of the system, thereby reducing the cost to each individual campus. In addition, the narrow selection of curricular programs available at many for-profit institutions is priced to yield the maximum profit (Morey, 2004) and the higher proportions of part-time faculty who are almost always non-tenure track lead to lower personnel costs.

The existence of for-profit institutions and the diversity within the sector may provide a niche for students who might not otherwise have access to postsecondary education, but the benefits to such students have not been weighed against the potential problems - such as attrition and high default rates-that students from the same population may face. Additionally, although the number of high school graduates may actually be in decline (Eckel, 2008), the number of students returning to postsecondary education is increasing (Breneman, Pusser, \& Turner, 2006) and traditional institutions may not be able to meet the growing demand (Glass, 1995). As students may increasingly turn to for-profit institutions to accommodate their higher education goals, it is important that researchers 
continue to examine this sector to ensure that the interests of students are guarded against purely financial objectives.

\section{Tensions and Unanswered Questions}

\section{The Accountability Climate}

Accountability is a concept that is continually evolving, but generally refers to how well an individual or organization meets its responsibilities to the public (Schmidtlein \& Berdahl, 2005). Demands for accountability arise from the public, state, and federal governments and include a range of measures including the requirement to explain their mission, purpose, and contributions to the public (Gladieux \& King, 1999; McGuinness, 1999; Schmidtlein \& Berdahl, 2005; Zumeta, 2001). Accountability can be measured by how well an institution's curriculum meets students' and employers' needs (Altbach, 1999), how fiscally efficient an institution is with its funds, and how well its use of public resources contribute to American society (Schmidtlein \& Berdahl, 2005). On this last point, the federal government exerts some control over higher education institutions by tying accountability requirements to federal research and development funds and financial aid dollars. Although the result is forced compliance with various guidelines and intrusion of external control, most institutions continue to accept federal funds out of need (Gladieux \& King, 1999).

Proponents of the for-profit sector claim that use of public monies to support for-profit higher education is a good investment because institutions in this sector are educationally effective and operationally efficient (Sperling \& Tucker, 2006). Supporters of for-profits argue that these institutions are highly accountable to the public in their low capital investment requirements, profitability, and rates of return to the nation's purse via greater tax payments (Kinser, 2007; Morey, 2001, 2004; Ortmann, 2001; Sperling \& Tucker, 2006). Despite such claims, Laband and Lentz (2004) found no significant differences in the cost per student at for-profit and private non-profit institutions, calling into question the argument that for-profit institutions are more efficient than private non-profit institutions. Most of the arguments about the effectiveness of private for-profit higher education come from a business-minded perspective and ignore other important measures of accountability, such as promoting the public good, contributing to the nation's "intellectual capital," and providing recreational and cultural services to the surrounding community (Heller, 2003).

From a corporate perspective, looking at students as consumers and clients may have the positive benefit of pushing an organization to be more studentcentered. However, students who are pursuing higher education for the first time may not be fully informed about the relative risks and potential gains of choosing 
to attend a for-profit institution. In this regard, future research should focus on how effectively for-profits achieve the policy goals driving the legislation that allows for-profits to obtain public resources. As it pertains to students, these goals include improving not only students' access but also retention-particularly degree completion rates-and preparing students for active participation in the social and political fabric of the nation. Future research should also consider factors that are strongly associated with persistence, including student satisfaction, sense of belonging, and sense of the institution's educational quality (Strauss \& Volkwein, 2004).

Researchers should also explore how well for-profit institutions expand access opportunities for students. Furthermore, in-depth examination of the support services and graduation rates for students who take out significant loans is imperative for assessing for-profit institutions' use of public funds. Are students graduating from for-profit institutions at rates that are consistent with traditional colleges and universities? Are there patterns to suggest that first-generation college students, students of color, or other historically marginalized populations drop out and default on their loans at higher rates than other students? If so, what measures need to be implemented to ensure that for-profit institutions are accommodating the financial and educational needs of these students in order to foster their retention and persistence? Are students acquiring the skills necessary to be productive and engaged members of a democratic society? Are they developing leadership skills? Are they obtaining better paying jobs?

The above questions lead to another related and important line of inquiry. Future research needs to consider the role of accreditation agencies. If future studies indicate that for-profit institutions are not as effective or efficient as their public and private non-profit counterparts, policymakers will need to understand how the ineffective for-profit institutions are becoming accredited. In addition, the accreditation should be examined to determine whether the standards used to accredit institutions are appropriate.

\section{Business and Individual Interests Versus Public Benefits}

Corporate language pervades the writing on for-profit higher education which pushes education toward a business-oriented perspective and away from a service-oriented one. Pusser and Doane (2001) claim that the term "market" which is sprinkled throughout the literature connotes concepts of supply and demand, consumers, pricing, competition, marketing, and so forth. Of course, since for-profit institutions are in the business of education, it should not be surprising. However, this sort of language may signal a shift in thinking about the values and goals of higher education and raises several issues.

First, how is it that business standards have become acceptable measures of performance? Why should accountability standards be driven primarily by 
private market practices? While it is true that the accreditation standards of some agencies place great emphasis on student learning outcomes and other non-market driven performance indicators, we do not know whether those standards are exerting any measurable influence on the for-profit sector. Therefore, since relatively little is known about what for-profit institutions contribute to society and to students, in terms of learning outcomes, future research should examine the contributions these institutions make that are beyond the market-driven indicators of success and accountability. Additionally, much of the current literature focuses on the multi-campus, publicly owned, accredited, and degree-granting institutions such as the Apollo Group's University of Phoenix and the DeVry Institute (Kinser, 2005). Without more data on all for-profit institutions, including accredited non-degree granting institutions and non-accredited institutions, it is difficult to accurately assess the effectiveness of the for-profit sector and its impact on the rest of the system of higher education. Future researchers should examine a broader variety of institutions within the sector with particular attention to the outcomes of distance learning. Focusing on different institutions within the for-profit sector might also shed more light on the perception of high loan default rates of for-profit students and graduates. In addition, such an examination might tell us more about how for-profit institutions function, what lessons traditional institutions can be learned from them, and what additional benefits are provided to individuals and society by the different institutions.

Second, one of the major tensions confronting for-profit institutions seems to concern the question of whether education is solely about individual gains. Forprofit institutions' emphasis on job training and preparation implies that it is primarily individuals who benefit from postsecondary education. Although most scholars agree that for-profit institutions view education as a commodity (Lechuga, 2008) and are oriented to the enhancement of private benefits (Breneman, 2005, 2006; Pusser \& Doane, 2001), the evidence is mixed as to whether for-profits consistently provide a combination of public and private benefits. On one hand, for-profit institutions seek to help their graduates attain jobs, increase their social mobility, increase their personal status, and experience better health. On the other hand, for-profits are also thought to promote public benefits including an increased tax base premised on higher earnings, better workplace preparation, and greater levels of civic engagement (Pusser \& Doane, 2001). On this last measure, however, Kinser (2007) finds that students from forprofit institutions demonstrate lower levels of civic engagement than students at traditional institutions. Nevertheless, for-profits may serve the public interest by educating students efficiently and cost-effectively, preparing students to participate in the workforce, and providing access to higher education for underserved populations (Lechuga, 2008). There are conflicting perspectives about for-profit institutions resulting in what one researcher calls a 
"cacophonous" set of reactions to the continuing growth of for-profit higher education (Kirp, 2003). Breneman (2005) claims that because the trend toward market dependence is likely to continue, the U.S. system of higher education will need to be more cognizant of preserving its public purposes. Therefore, more research needs to be done to assess whether the for-profit sector overall and institutions in particular make contributions to society and culture.

\section{The Future of For-Profit Higher Education}

Much of the literature suggests that for-profit higher education is focused on career and vocational training, which prompts one to first consider the distinction between education and training, and second whether the sector provides education or training. A broad-based liberal education aims to focus on helping students develop critical thinking skills necessary for lifelong learning and engagement with society, while pure job training seems to be focused on providing students with a narrow set of skills necessary for increasingly complex jobs, but which likely have limited applicability. The absence of general education requirements to help students develop critical thinking skills and other competencies important to holistic development suggests that for-profit institutions are engaged in job training.

Although having a specific niche purpose may not be a negative thing for institutional diversity in the U.S. system of higher education, institutions of higher learning have traditionally been seen as places where teaching, research, and service are conducted. Colleges and universities have also traditionally contributed to the communities in which they are located (Cohen, 1998), so it would be worthwhile to examine whether communities benefit from local forprofit institutions. It is the expectation that institutions of higher learning provide a public service that provides a point of departure for offering considerations to the for-profit sector. Regardless of one's ideology regarding the compatibility of education and profit-making, it is conceivable that for-profit higher education has the potential to contribute to public and private benefits. What follows are recommendations for responding to some of the issues discussed in this review.

\section{Understanding the Institutional Diversity Within the For-Profit Sector}

Compared to other sectors of higher education, relatively little is known about the for-profit sector, yet it is clear that there is a massive range in the program offerings and delivery across institutions. For-profit institutions that do not receive federal aid could find ways to participate in surveys administered by the National Center for Education Statistics, or they could work together to gather the information themselves and sort it in ways that distinguish among institutional 
types (e.g. multi-campus versus single campus). Regular compilation of traditional measures of accountability, along with for-profits' preferred market indicators of success, could help us better understand the landscape. Such selfstudy could help researchers, scholars, and policymakers understand the contributions for-profits make to the nation, and it could help educational leaders improve coordination among sectors so as to maximize mission differentiation and avoid duplication.

For-profit participation in national studies about higher education would also help to complete our understanding of which students are still being denied access to higher education by all sectors. Such participation and/or self-study would help institutions to better understand the characteristics of the students they attract, the challenges those students face, and how they can better serve them. Finally, coordinated self-study might have the effect of improving quality since institutions that are poorly reviewed will be more likely to want to improve their market competitiveness with students.

\section{Providing Adequate Student Support}

Although the research literature cannot fully explain why students at forprofit institutions seem to be more likely to default on their loans compared to all other students, for-profit institutions can take several steps to help students avoid this situation. First, they can re-evaluate their cost structures to determine whether reigning in their profit-making goals could help lower the cost of tuition for students and in turn lead to lower rates of borrowing. Second, they can educate students about the practical aspects of borrowing and repayment by offering loan counseling and consumer education programs (Gross et al., 2009). Finally, they can revamp the no-frills approach to education and develop student retention services. A few reports suggest that some for-profits have such mechanisms in place (see e.g., Gonzalez, 2009; Wilson, 2010), and if that is the case, then those institutions can serve as models for other for-profit institutions that have not yet developed those services.

\section{Maximizing Educational Potential}

Ultimately, students and for-profit institutions mutually benefit from program offerings that are of high quality and provide students with the specialized skills required by today's professions. Students gain the ability and perhaps credentials to enter careers to which they did not previously have access and institutions earn a profit and reputation for producing a quality product — seen either as the education or the student - that will likely attract more students and investors. However, this beneficial relationship is dependent upon quality and it therefore behooves institutions to engage in critical quality control. Regional and 
national accreditors could assess the various factors that contribute to the quality of education and develop consequences with real "teeth" for institutions that do not have quality offerings.

Finally, high quality job training may still not equate to education and suggests that for-profits might consider identifying a set of basic competencies needed for full participation in the nation's social, political, and economic worlds, such as critical thinking, information literacy, and understanding of civic life. Because these skills would help students with problem-solving and other related challenges in the careers they are training for, educating students to develop these competencies would still be in line with their missions, particularly since employers may be seeking more well-rounded rather than narrowly trained employees (Wilson, 2010). For-profit institutions' advisory boards could assist in finding ways to help students develop these competencies through existing courses. If for-profit institutions broaden their curricula in this way, they would contribute to the public good and therefore provide a return to society for its investment in for-profit higher education.

\section{References}

Academy of Art University. (n.d.). Academy of Art University. Retrieved April 19, 2010, from www.academyart.edu

Accrediting Commission of Career Schools and Colleges. (n.d.). Standards of accreditation. Retrieved April 10, 2010, from www.accsc.org/Content/Accreditation/StandardsofAccreditation/Standard s.asp

Accrediting Council for Independent Colleges and Schools. (n.d.). Accreditation criteria policies, procedures, and standards. Retrieved April 10, 2010, from www.acics.org/publications/criteria.aspx\#AppD

Alexander, F. K. (2002). The federal government, direct financial aid, and community college students. Community College Journal of Research \& Practice, 26(7/8), 659-679.

Altbach, P. G. (1999). Patterns in higher education development. In P. G. Altbach, R. O. Berdahl, \& P. J. Gumport (Eds.), American higher education in the twenty-first century: Social, political, and economic challenges (pp. 1537). Baltimore: The Johns Hopkins University Press.

Baum, S., \& Ma, J. (2007). Education pays 2007: The benefits of higher education for individuals and society. New York: The College Board.

Bowen, H. R. (1977). Investment in learning: The individual and social value of American higher education. San Francisco: Jossey-Bass.

Bowen, H. R. (1982). The state of the nation and the agenda for higher education. San Francisco: Jossey-Bass. 
Breneman, D. W. (2005). Entrepreneurship in higher education. New Directions for Higher Education, 129, 3-9.

Breneman, D. W. (2006). Introduction. In D.W. Breneman, B. Pusser, \& S. E. Turner (Eds.), Earnings from learning: The rise of for-profit universities (pp. ix-Xv). Albany: SUNY Press.

Breneman, D. W., Pusser, B., \& Turner, S. E. (2006). The contemporary provision of for-profit higher education: Mapping the competitive market. In D.W. Breneman, B. Pusser, \& S. E. Turner (Eds.), Earnings from learning: The rise of for-profit universities (pp. 3-22). Albany: SUNY Press.

Brint, S., \& Karabel, J. (1989). The diverted dream: Community colleges and the promise of educational opportunity in America, 1900-1985. New York: Oxford University Press.

California Southern University. (n.d.) California Southern University. Retrieved April 19, 2010, from www.calsouthern.edu/

Capella University. (n.d.). Capella University. Retrieved April 19, 2010, from www.capella.edu

Cohen, A. M. (1998). The shaping of American higher education. San Francisco: Jossey-Bass.

Cohen, A. M., \& Brawer, F. B. (1982). The American community college. San Francisco: Jossey-Bass.

Deil-Amen, R. (2006). To teach or not to teach "social" skills: Comparing community colleges and private occupational colleges. The Teachers College Record, 108(3), 397-421.

Dewey, J. (1916). Democracy and education: An introduction to the philosophy of education. New York: The Macmillan Company.

Dynarski, M. (1994). Who defaults on student loans? Findings from the National Postsecondary Student Aid Study. Economics of Education Review, 13(1), $55-68$.

Eckel, P. (2008). Mission diversity and the tension between prestige and effectiveness: An overview of U.S. higher education. Higher Education Policy, 21(2), 175-192.

Floyd, C. (2005). For-profit degree-granting colleges: Who are these guys and what do they mean for students, traditional institutions, and public policy? Higher Education: Handbook of Theory and Research, 20, 539-589.

Gladieux, L. E., \& King, J. E. (1999). The federal government and higher education. In P. G. Altbach, R. O. Berdahl, \& P. J. Gumport (Eds.), American higher education in the twenty-first century: Social, political, and economic challenges (pp. 151-182). Baltimore: The Johns Hopkins University Press. 
Glass, S. (1995). Hire education: An affordable college sets the standard for career training. Policy Review, 72, 44.

Gonzalez, J. (2009, November 8). For-profit colleges, growing fast, say they are key to Obama's degree goals [Electronic version]. The Chronicle of Higher Education. Retrieved April 6, 2010, from chronicle.com/article/For-Profit-Colleges-Say-The/49068

Gross, J. P. K., Cekic, O., Hossler, D., \& Hillman, N. (2009). What matters in student loan default: A review of the research literature. Journal of Student Financial Aid, 39(1), 19-29.

Grubb, W. N., \& Turna, J. (1991). Who gets student aid? Variations in access to aid. Review of Higher Education, 14(3), 359.

Gumport, P. J. (2001). Built to serve: The enduring legacy of public higher education. In P. G. Altbach, P. J. Gumport, \& D. B. Johnstone (Eds.), In defense of American higher education. Baltimore: The Johns Hopkins University Press.

Heller, D. E. (2003, November 14). Not all institutions are alike. The Chronicle of Higher Education, 50(12), B7.

Kinser, K. (2005). A profile of regionally accredited for-profit institutions of higher education. New Directions for Higher Education, 129, 69-83.

Kinser, K. (2007). Dimensions of corporate ownership in for-profit higher education. Review of Higher Education, 30(3), 217-245.

Kinser, K., \& Levy, D. C. (2006). For-profit higher education: U.S. tendencies, international echoes. International Handbook of Higher Education, 18, 107-119.

Kirp, D. L. (2003). Education for profit. Public Interest, 152, 100.

Laband, D., \& Lentz, B. (2004). Do costs differ between for-profit and not-forprofit producers of higher education? Research in Higher Education, 45(4), 429-441.

Lechuga, V. (2008). Assessment, knowledge, and customer service: Contextualizing faculty work at for-profit colleges and universities. Review of Higher Education, 31(3), 287-307.

McGuinness, A. C. (1999). The states and higher education. In P. G. Altbach, R. O. Berdahl, \& P. J. Gumport (Eds.), American higher education in the twenty-first century: Social, political and economic challenges (pp. 183215). Baltimore: The Johns Hopkins University Press.

Morey, A. I. (2001). The growth of for-profit higher education: Implications for teacher education. Journal of Teacher Education, 52(4), 300-311.

Morey, A. I. (2004). Globalization and the emergence of for-profit higher education. Higher Education, 48(1), 131-150. 
National Center for Education Statistics. (1999). Students at private, for-profit institutions (No. NCES 2000-175). Washington, DC: U.S. Department of Education.

National Center for Education Statistics. (2008). The condition of education 2008 (No. NCES 2008-031). Washington, DC: U.S. Department of Education.

National Center for Education Statistics. (2009a). Enrollment in postsecondary institutions, Fall 2007; Graduation rates, 2001 \& 2004 cohorts; and fiscal year 2007 (No. NCES 2009-155). Washington, DC: U.S. Department of Education.

National Center for Education Statistics. (2009b). Postsecondary institutions and price of attendance in the United States: Fall 2008, degrees and other awards conferred: 2007-08, and 12-Month Enrollment: 2007-08 (No. NCES 2009-165). Washington, DC: U.S. Department of Education.

National Center for Education Statistics. (2010). Digest of education statistics 2009 (No. NCES 2010-013). Washington, DC: U.S. Department of Education.

Ortmann, A. (2001). Capital romance: Why Wall Street fell in love with higher education. Education Economics, 9(3), 293-311.

Perkin, H. (2007). History of universities. In J. J. Forest \& P. G. Altbach (Eds.), International handbook of higher education (pp. 159-205). The Netherlands: Springer.

Pusser, B., \& Doane, D. J. (2001). Public purpose and private enterprise: The contemporary organization of postsecondary education. Change, 33(5), 18.

Ruch, R. S. (2001). Higher ed, inc.: The rise of the for-profit university. Baltimore: The Johns Hopkins University Press.

Schmidtlein, F. A., \& Berdahl, R. O. (2005). Autonomy and accountability: Who controls academe? In P. G. Altbach, R. O. Berdahl, \& P. J. Gumport (Eds.), American higher education in the twenty-first century: Social, political, and economic challenges (2nd ed., pp. 71-90). Baltimore: The Johns Hopkins University Press.

Slaughter, S., \& Rhoades, G. (2005). Markets in higher education: Students in the seventies, patents in the eighties, and copyrights in the nineties. In P. G. Altbach, R. O. Berdahl, \& P. J. Gumport (Eds.), American higher education in the twenty-first century: Social, political, and economic challenges (2nd ed., pp. 486-516). Baltimore: The Johns Hopkins University Press.

Sperling, J. G., \& Tucker, R. W. (2006). For-profit higher education: Developing a world-class workforce. New Brunswick, NJ: Transaction Publications. 
Strauss, L. C., \& Volkwein, J. F. (2004). Predictors of student commitment at two-year and four-year institutions. Journal of Higher Education, 75(2), 203-228.

University of Phoenix. (n.d.). University of Phoenix. Retrieved April 19, 2010, www.phoenix.edu

Thelin, J. R. (2004). A history of American higher education. Baltimore: The Johns Hopkins University Press.

Volkwein, J. F., Szelest, B. P., Cabrera, A. F., \& Napierski-Prancl, M. R. (1998). Factors associated with student loan default among different racial and ethnic groups. Journal of Higher Education, 69(2), 206-237.

Wilson, R. (2010, February 7). For-profit colleges change higher education's landscape [Electronic version]. The Chronicle of Higher Education. Retrieved April 6, 2010, from chronicle.com/article/For-Profit-CollegesChange-/64012/

Zumeta, W. (2001). Public policy and accountability in higher education: Lessons from the past and present for the new millennium. In D. E. Heller (Ed.), The states and public higher education policy: Affordability, access, and accountability (pp. 155-197). Baltimore: The Johns Hopkins University Press.

\begin{abstract}
Author
Melissa L. Millora is a third-year PhD student in the Higher Education and Organizational Change program in UCLA's Department of Education. Her current research focuses on the role of colleges and universities in promoting civic and global engagement, and how college students understand race and national identity after participating in international education experiences.
\end{abstract}

